\title{
US bioethicists say continue human cloning moratorium
}

Having rushed to meet the 90-day deadline set by US President Bill Clinton, the members of the National Bioethics Advisory Commission (NBAC; Washington, DC) recommended in its report issued in June that the moratorium on federally sponsored human cloning efforts should continue. It also urged that a similar ban should be extended by legislation to the private sector. In both cases, however, it asked that legislation should allow the ban to lapse after three to five years, thereby permitting cloning issues to be reexamined formally.

The NBAC report-and similar recommendations in Europe and Japan (see "Europe/Japan face up to legal hurdles to cloning")-was prompted by the cloning of Dolly the sheep by researchers at the Roslin Institute in Edinburgh. In accepting the commission report, Clinton called upon the private sector to continue observing a voluntary moratorium and promised to submit a bill to Congress soon that would achieve the full public-private ban that the commission recommends. Meanwhile, several members of the US Congress, including Kit Bond (RMissouri), are already drafting bills on human cloning. If enacted, any legislation would mark the first time that the US government had issued such a blanket ban on a biomedical research and development activity. In earlier NBAC hearings, lawyers expressed the view that a ban might raise constitutional issues.

The members of the NBAC did not reach agreement over the many detailed ethical arguments around human cloning efforts. But they did find common ground in safety issues and used that touchstone in arguing for a continued moratorium.

NBAC members pointed to some of the technical difficulties that the Roslin researchers had encountered in sheep cloning as being "probably sufficient to justify a prohibition on cloning human beings." They had "concerns about direct physical harms" to offspring and cited scientific uncertainties as sources of potential harm or failure. Factors that precluding human cloning in their view included species differences between sheep and humans in the stability of genetic imprinting, uncertainties over the developmental programming of adult nuclei, and the possible induction of mutations leading to malformation, cancer, or other diseases.

The NBAC report emphasizes that these recommended restrictions be applied narrowly to attempts to produce individual humans from cloned somatic cells. Existing rules already severely restrict federally sponsored research on human embryos and forbid their deliberate creation or destruction for research purposes. But NBAC wants to ensure that the ban on investigations of early-stage human embryos derived from cloned cells would also apply to the private sector.

Importantly, the report stresses to legislators that techniques such as cloning human DNA or establishing somatic human cell lines in vitro "are well-established scientific techniques" that are and should be free to continue under current federal guidelines and regulations. Furthermore, the NBAC does not call for any additional restrictions on cloning research on nonhuman species, seemingly putting the development and expansion of transgenic animals in the clear.

Representatives of both the biotechnology and pharmaceutical industries appear to satisfied with the NBAC's carefully circumscribed recommendations. But they are concerned that the president and Congress exercise similar care in drafting and enacting legislation.

\section{Jeffrey L. Fox} Editor's note: Shortly after accepting the NBAC report, Clinton submitted to Congress the "Cloning Prohibition Act of 1997," a legislative proposal prohibiting any attempt to use somatic cell nuclear transfer technology to create human beings. Commenting on the White House proposal, BIO (Washington, DC) president Carl Feldbaum said that BIO "could not support the bill in its current form," noting in particular its fuzziness concerning technical issues, "Draconian penalties," and lack of provision for including or preempting individual state legislative efforts. It seems likely that the bill will need to undergo significant redrafting before it will get the neccesary political and industry support.

\section{Europe/Japan face up to legal hurdles to cloning}

As in the United States, human reproductive cloning will be banned in Europe and Japan if reports from ethical groups are translated into law. The Group of Advisors on the Ethical Implications of Biotechnology (GAEIB) sent its advice to the European Commission (EC; Brussels) on May 30, and two Japanese groups-the Committee for Basic Plans for Life Sciences and the Committee for Life Sciences--will report to the Japanese government in July. While legislators are receptive to the advice, the translation of ethical opinions into law is far from straightforward.

"The key element is how people act with this advice and incorporate it into legislation," says Andrew Dickson, secretary general of EuropaBio, which represents the interests of over 500 European bioindustrial companies. "It will only be possible if the wording is correct. Legislation must show what will and won't be allowed."

Anne McLaren, the reporter for GAEIB, agrees that lawyers will face difficulties in drawing the lines correctly. "Defining what one means is essential," she says. "[One needs to distinguish] animal from human, reproductive from nonreproductive." They cannot simply ban nuclear transfer, she says, or ban cloning. "We have to stress that not all cloning is nuclear transfer, and that not all nuclear transfer is cloning," McLaren adds.

Noelle Lenoir, chair of GAEIB, also emphasizes the different types of cloning. "There is a strict difference between reproductive cloning and cloning as a method." Indeed, GAEIB has advised the EC that all animal cloning, both reproductive and cell cloning should be permitted, as should the cloning of human parts for organ replacement and replacement skin. However, reproductive human cloning should be outlawed. "Instrumentalization [a term used by GAEIB, describing the use of humans as tools] and eugenics render any such acts ethically unacceptable." Even with the knowledge that there may be benefits associated with reproductive human cloning, Lenoir says: "It is a matter of principle." 